\title{
DEKOLORISASI SENYAWA AZO LIMBAH REMAZOL GOLDEN YELLOW OLEH BIOADSORBEN ECENG GONDOK (Eichhornia crassipes)
}

\author{
Ika Nur Fitriani *1, Anggi Ristiyana Puspitasari², Rizki Nor Amelia ${ }^{2}$ \\ ${ }^{1}$ Jurusan Kimia, Fakultas Sains dan Teknologi, UIN Walisongo Semarang \\ 2Jurusan Pendidikan Kimia, Fakultas MIPA, Universitas Negeri Yogyakarta \\ *E-mail: ikanurf@walisongo.ac.id
}

\begin{abstract}
Abstrak
Telah dilakukan penelitian tentang adsorbsi senyawa azo Remazol Golden Yellow dari limbah cair zat warna sintetis menggunakan adsorben dari eceng gondok (Eichhornia crassipes). Penelitian ini bertujuan untuk mengetahui kondisi optimal eceng gondok (Eichhornia crassipes) sebagai bioadsorben limbah zat warna Remazol Golden Yellow dan mengetahui kadar ppm Remazol Golden Yellow maksimum dalam limbah zat warna sintetis yang dapat diserap oleh bioadsorben eceng gondok (Eichhornia crassipes). Subyek penelitian adalah eceng gondok yang teraktivasi NaOH $2 \%$ dengan waktu perendaman 24 jam. Obyek penelitian adalah efisiensi adsorpsi eceng gondok (Eichhornia crassipes) terhadap zat warna sintetis-reaktif Remazol Golden Yellow. Variabel bebas yang dipakai adalah variasi massa. Daya adsorbsi ditentukan dengan dengan membandingkan konsentrasi Remazol Golden Yellow sebelum dan setelah adsorbsi. Hasil penelitian menunjukkan bahwa semakin besar massa bioadsorben, efisiensi adsorbsi juga akan semakin besar dan adsorbsi optimum variasi massa Remazol Golden Yellow diperoleh pada massa adsorben 2,5 gram/100 mL dengan efisiensi adsorbsi 74,767\% .
\end{abstract}

Kata kunci: bioadsorben, eceng gondok, Remazol golden yellow

\begin{abstract}
Research of decolorization azo compound from Remazol Golden Yellow in waste water reactivesynthetic dyes using water hyacinth bioadsorben (Eichhornia crassipes) were conducted. This research aims that finding out mass effect of water hyacinth (Eichhornia crassipes) as bioadsorben of Remazol Golden Yellow and determining optimal mass of water hyacinth (Eichhornia crassipes) to adsorp Remazol Golden Yellow. Subject of this research were water hyacinth which activated with $\mathrm{NaOH} 2 \%$ in 24 hours. Object of this research were adsorption efficiency of water hyacinth (Eichhornia crassipes) to reactive-synthetic dyes Remazol Golden Yellow. Dependent variable in this study is variation of mass. Adsorption efficiency determined by comparing the concentration of Remazol Golden Yellow before and after adsorption. This implies that the greater the mass of the bioadsorben, adsorption efficiency was also greater and the bioadsorben is effective on mass $2.5 \mathrm{gram} / 10 \mathrm{~mL}$ which have adsorption efficiency of $74.767 \%$.
\end{abstract}

Keywords: bioadsorben, remazol golden yellow, water hyacinth 


\section{Pendahuluan}

Industri tekstil saat ini merupakan salah satu industri yang menjanjikan. Hal ini menyebabkan perkembangan industri tekstil di Indonesia semakin pesat, Namun, dibalik perkembangan industri teksti yang sangat pesat dan prospek yang menjanjikan tersebut, terdapat masalah-masalah yang perlu mendapatkan perhatian. Salah satu masalah yang perlu mendapat perhatian pada usaha industri tekstil ialah masalah tentang limbah hasil produksinya yang dapat mencemari lingkungan. Hal ini dikarenakan umumnya industri tekstil cenderung membuang limbahnya langsung di selokan sekitar rumah atau lokasi pembatikan.

Limbah industri tekstil sebagian besar berupa zat warna cair yang dihasilkan dari proses pencelupan. Pada proses pencelupan, dihasilkan limbah tekstil yang masih banyak mengandung zat warna yang disebabkan tidak terserapnya seluruh warna ke dalam kain. Zat warna yang digunakan kebanyakan adalah zat warna reaktif karena membrikan kilap warna yang baik. Salah satu zat warna yang sering digunakan adalah Remazol Golden Yellow yang mengandung senyawa azo. Sekitar 30-70\% dari senyawa azo yang digunakan akan terfiksasi pada kain dan sisanya akan dibuang sebagai limbah dan dapat mencemari lingkungan (Bumpus, 1995 dalam ST Ambrosio, 2004).

Senyawa azo adalah senyawa yang cukup stabil karena senyawa ini disintesis agar tidak mudah rusak oleh perlakuan kimia maupun perlakuan photolitik. Oleh karena itu, jika terbuang ke perairan, senyawa ini dapat bertahan cukup lama dan mengalami akumulasi. Pada tingkat tertentu, akumulasi senyawa ini dapat menimbulkan dampak negatif terhadap daya dukung lingkungan. Menurut Uni Eropa, senyawa reaktif azo tergolong bahan dengan bahaya rendah. Zat warna azo umumnya mempunyai $\mathrm{LD}_{50}$ sebesar $250-200 \mathrm{mg} / \mathrm{kg}$ berat badan dan hanya sedikit yang mempunyai $\mathrm{LD}_{50}$ di bawah $250 \mathrm{mg} / \mathrm{kg}$ berat badan. Namun, meski senyawa ini kadar bahayanya rendah, keberadaannya dalam air dapat menghambat penetrasi sinar matahari ke dalam air, sehingga dapat mengganggu aktivitas fotosintesis mikroalga yang hidup di dalamnya. Hal ini berdampak pada terpicunnya aktivitas organisme anoksik-anaerobik yang kekurangan pasokan oksigen untuk menghasilkan produk berbau tak sedap dan berpotensi mencemari lingkungan. Selain itu, perombakan senyawa azo pada dasar perairan secara anaerobik dapat menghasilkan senyawa amina aromatik yang mungkin lebih beracun daripada senyawa azo sendiri (Van der Zee, 2002).

Oleh karena itu, perlu dilakukan tindakan untuk menangani masalah pencemaran oleh zat warna Remazol Golden Yellow beserta kandungan senyawa azo didalamnya. Saat ini beberapa penanganan memang telah dilakukan, baik secara kimia, fisika, biologi, maupun kombinasi dari ketigannya. Beberapa penelitian penghilangan warna dan senyawa organik yang ada dalam limbah cair industri tekstil juga telah dilakukan, misalnya dengan cara kimia menggunakan koagulan, secara fisika dengan sedimentasi, dan secara biologi dengan mereduksi senyawa organik dari limbah cair industri tekstil.

Kenyataannya, upaya-upaya tersebut belum mencapai hasil yang memuaskan. Penghilangan zat warna secara kimia menggunakan koagulan akan menghasilkan lumpur dalam jumlah yang cukup besar. Menurut Peraturan Pemerintah No.19 tahun 1994, lumpur yang dihasilkan industri tekstil diklasifikasikan sebagai limbah B3, sehingga membutuhkan pengolahan lebih lanjut terhadap lumpur yang terbentuk. Penanganan lanjutan ini tentu akan menaikkan biaya operasional unit pengolahan limbah. Sementara itu, penggunaan karbon aktif untuk menghilangkan warna juga memerlukan biaya yang besar, sebab harga karbon aktif relatif mahal. Penanganan secara biologi juga kurang memuaskan karena zat warna mempunyai sifat tahan terhadap degradasi biologi (recalcitrance). Oleh karena itu, diperlukan altematif baru yang lebih efisien untuk menangani limbah cair zat warna Remazol Golden Yellow beserta kandungan senyawa azo di dalamnya. Salah satu cara yang dapat

41

Copyright (C) 2018 WJC | ISSN 2621-5985 (online) | ISSN 2549-385X (print)

Volume 2, Nomor 2, 2019 
dilakukan adalah menggunakan adsorben tumbuhan eceng gondok (Eichornia crassipes).

Eceng gondok adalah salah satu jenis tumbuhan air yang memiliki kecepatan tumbuh tinggi. Eceng gondok sering dianggap sebagai gulma karena dapat dengan mudah menyebar melalui saluran air ke badan air lainnya dan karena pada musim kemarau tanaman ini mampu menyusutkan air 3 atau 4 kali lebih cepat dibanding jika tidak ada eceng gondoknya. Sedangkan pada musim hujan perkembangan tanaman ini sangat cepat yang menyebabkan eceng gondok dapat menutupi permukaan dan saluran-saluran air. Namun dibalik potensinnya sebagai gulma, eceng gondok dapat menyerap senyawa nitrogen dan fosfor dari air yang tercemar, sehingga berpotensi untuk digunakan sebagai komponen utama pembersih air limbah dari berbagai industri dan rumah tangga (Ratnani, 2008:43)

Tanaman eceng gondok dapat membentuk zat fitosidorof di bagian akar. Fitosidorof akan mengikat logam dan kemudian mengikatnya di bagian akar, zat ini akan mempermudah logam melintasi epidermis akar dan akan masuk ke dalam sel-sel akar (Nda, 2002). Tanaman eceng gondok mengandung $17,2 \%$ protein kasar, $15-18 \%$ serat dan $16-20 \%$ abu, yang terdiri dari beberapa komponen, seperti: karbon, belerang, kalsium, kalium, mangan, hidrogen dan lain-lain. Komponen kimia yang terkandung dalam tanaman eceng gondok tergantung pada kandungan unsur hara tempat tumbuh dan sifat daya serap tanaman ini. Selain itu, eceng gondok mengandung protein lebih dari 11,5\% atas dasar berat kering dan mengandung selulosa yang lebih tinggi daripada non-selulosanya, seperti; lignin, abu, lemak dan zat-zat lain. (Dewi Erina Sawitri dan Tri Sutrisno, $2008: 1$ )

Tanaman eceng gondok juga mempunyai kemampuan sebagai biofilter dengan adanya mikrobia rhizosfera pada akar dan didukung oleh daya absorbsi serta akumulasi yang besar terhadap bahan pencemar tertentu. Oleh karena itu, tanaman eceng gondok dapat dimanfaatkan sebagai salah satu alternatif pengendali pencemaran di perairan (Marianto, 2001). Dengan beberapa kelebihan tersebut, peneliti akan membuat sebuah bioadsorben dari eceng gondok yang berpotensi untuk menyerap zat warna Remazol Golden Yellow yang terkandung dalam limbah tekstil.

\section{Metode Penelitian}

Alat: Spectrofotometer UV-VIS 2450 keluaran Shimidzu, Spectronic Genesys-2, neraca analiti, oven, alat-alat gelas

Bahan: eceng gondok (Eichhornia crassipes), zat warna Remazol Golden Yellow, aquades, larutan $\mathrm{NaOH} 2 \%$

\section{Prosedur Kerja}

1. Pembuatan larutan standar $\mathbf{1 0 0 0}$ ppm Larutan zat warna standar dapat dibuat dari 1 gram Remazol Golden Yellow yang dilarutkan dengan konsentrasi 1000 mL aquades.

2. Penentuan panjang gelombang maksimum

Larutan Remazol Golden Yellow dibuat 100 ppm, Diukur absorbansinya pada rentang panjang gelombang 400-500 nm dengan instrumen Spectrofotometer UV-Vis 2450 keluaran Shimidzu, dari data adsorbansi dapat diketahui panjang gelombang saat terjadi adsorbansi maksimum tersebut digunakan untuk penelitian selanjutnya.

3. Pembuatan kurva kalibrasi zat warna

Larutan warna dibuat dengan konsentrasi 20, 40, 60, 80, dan 100 ppm, diukur absorbansi dari masing-masing konsentrasi dengan Spectronic Genesys-20 pada panjang gelombang maksimum, dibuat kurva kalibrasi dari pengukuran absorbansi tersebut.

4. Pembuatan bioadsorben

Eceng gondok dicuci dengan aquades sampai bersih, lalu menghaluskannya dengan blender, diaktivasi dengan $\mathrm{NaOH}$ $2 \%$ dengan perbandingan 1:30 (w/v), dilakukan aktivasi selama 24 jam, dicuci dengan air hingga air cucian netral, dikeringkan dalam oven pada suhu $100^{\circ} \mathrm{C}$. 


\section{Uji kemampuan adsorben pada limbah untuk variasi massa}

Eceng gondok ditimbang masing-masing sebanyak 0,$5 ; 1,0 ; 1,5 ; 2,0$; dan 2,5 gram, dimasukkan masing-masing ke dalam wadah plastik, ditambahkan larutan Remazol Golden Yellow 100 ppm sebanyak $50 \mathrm{~mL}$ ke dalam masing-masing wadah plastik yang telah berisi eceng gondok, ditutup wadah plastik tersebut dan didiamkan selama 24 jam. Larutan Remazol Golden Yellow yang telah diadsorb lalu dianalisis dengan Spectronic Genesys-20.

\section{Hasil Penelitian dan Pembahasan}

Penelitian ini bertujuan untuk mengetahui efisiensi adsorpsi eceng gondok terhadap pewarna sintetis-reaktif Remazol Golden Yellow dengan uji pada variabel tertentu, yaitu massa bioadsorben dan variasi konsentrasi limbah zat warna. Adsorpsi adalah proses melekatnya partikel-partikel atau zat-zat pada permukaan. Adsorpsi terjadi jika gaya tarik menarik antar zat terlarut dengan permukaan penyerap dapat mengatasi gaya tarik menarik antar zat terlarut dengan permukaan. Zat atau molekul yang terserap ke permukaan disebut adsorbat sedangkan zat atau molekul yang menyerap disebut adsorben (Sukardjo, 1989: 190). Dalam penelitian ini digunakan eceng gondok sebagai adsorben dan limbah buatan dari pewarna Remazol Golden Yellow sebagai adsorbat.

Salah satu contoh zat warna yang banyak dipakai industri tekstil adalah Remazol Black, Red, dan Remazol Golden Yellow. Dalam pewarnaan, senyawa ini hanya digunakan sekitar 5\% sedangkan sisanya yaitu $95 \%$ akan dibuang sebagai limbah. Senyawa ini cukup stabil sehingga sangat sulit untuk terdegradasi di alam dan berbahaya bagi lingkungan apalagi dalam konsentrasi yang sangat besar karena dapat menaikkan COD (Chemical Oxygen Demand). Hal ini tentu saja dapat merusak keseimbangan ekosistem lingkungan yang ditandai dengan matinya organisme perairan di sekitar lokasi pembuangan limbah sehingga perlu pengolahan lebih lanjut agar limbah tekstil ini aman bagi lingkungan.

Penelitian diawali dengan

mempersiapkan alat dan bahan yang akan digunakan, kemudian menentukan panjang gelombang maksimum pewarna Remazol Golden Yellow yaitu dengan cara mengukur absorbansi larutan Remazol Golden Yellow 100 ppm dengan instrumen berupa Spektrofotometer UV-VIS 2450 keluaran dari Shimidzu. Penggunaan instrument Spektrofotometer UV-VIS 2450 dikarenakan zat yang akan dijerap merupakan zat warna. Pengukuran panjang gelombang maksimum dilakukan pada rentang panjang gelombang 300-500 $\mathrm{nm}$. Pada proses penentuan panjang gelombang maksimum ini didapatkan nilai panjang gelombang maksimum ( $\lambda$ maks) sebesar 409,6 nm. Panjang gelombang maksimum adalah panjang gelombang saat nilai adsorbansinya (serapannya) maksimum. Dibawah ini disajikan spektrum adsorpsi untuk penentuan panjang gelombang maksimum pada Gambar 1.

Larutan standar Remazol Golden Yellow dibuat dengan konsentrasi masing-masing 20, 40, 60, 80, 100 ppm. Absorbansi larutan standar tersebut selanjutnya diukur menggunakan instrumen berupa Spectronic Genesys-20 pada panjang gelombang maksimum $410 \mathrm{~nm}$. Dibawah ini disajikan kurva kalibrasi larutan standar pada Gambar 2. 


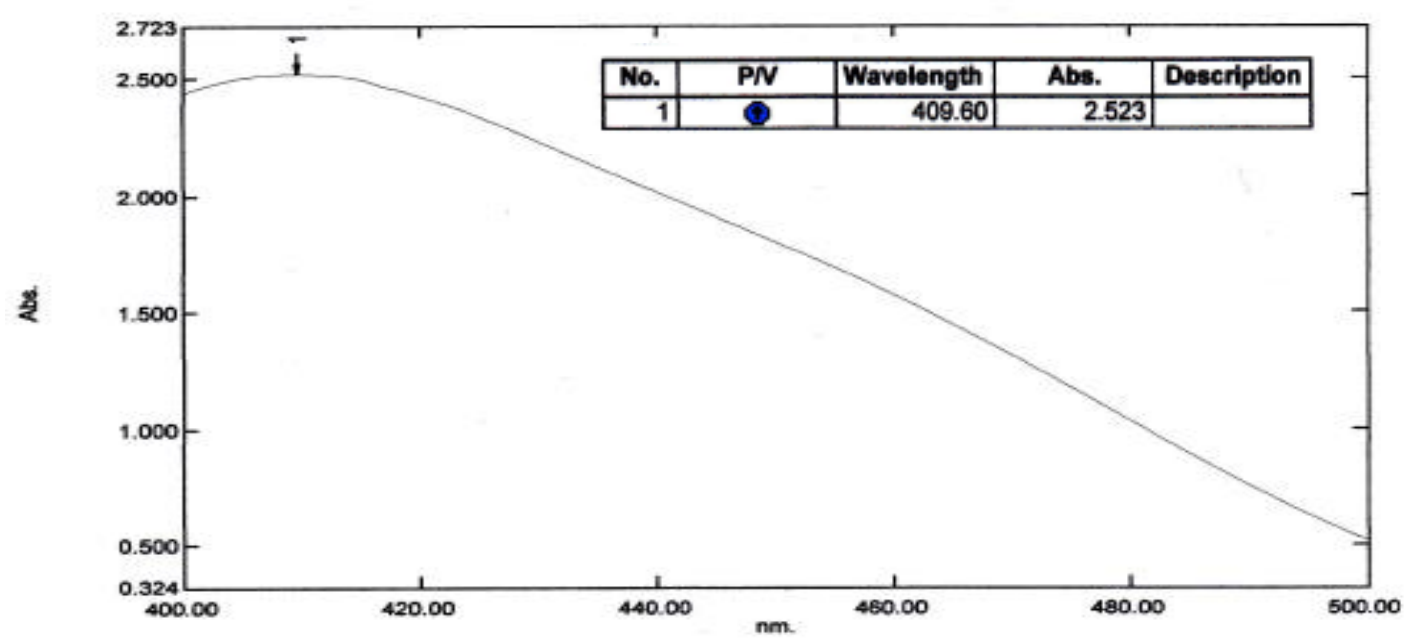

Gambar 1. Spectrum Peak Report Larutan Remazol Golden Yellow 100 ppm

Berdasarkan kurva kalibrasi antara konsentrasi larutan standar Remazol Golden Yellow dengan adsorbansinya maka diperoleh persamaan garis linear sebesar $\mathrm{y}=0,0274 \mathrm{x}+$ 0,0278 .

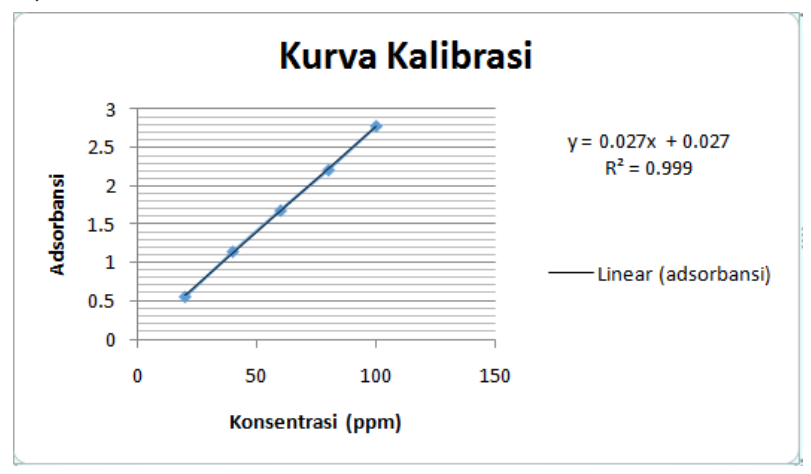

Penentuan persamaan garis untuk kurva kalibrasi larutan standar tersebut diperoleh derajat linearitas $(r)$ sebesar 0,9996. Harga $r$ hitung ini ternyata mendekati 1 artinya dapat disimpulkan bahwa persamaan regresi ini dapat digunakan untuk menghitung konsentrasi dari pewarna Remazol Golden Yellow.

Massa bioadsorben dan efisiensi adsorpsi (\%) pada konsentrasi limbah zat warna Remazol Golden Yellow sebesar 100 ppm dapat dilihat pada Tabel 1.

Gambar 2. Kurva kalibrasi larutan standar Remazol golden yellow

Tabel 1. Data Efisiensi Adsorbsi untuk Variasi Massa Adsorben

\begin{tabular}{|c|c|c|c|c|c|}
\hline \multirow{2}{*}{$\begin{array}{c}\text { Massa } \\
\text { bioadsorben } \\
\text { (gram) }\end{array}$} & Adsorbansi & \multicolumn{3}{|c|}{ Konsentrasi (ppm) } & Efisiensi \\
\cline { 3 - 5 } & & $\begin{array}{c}\text { C sebelum } \\
\text { adsorpsi (Co) }\end{array}$ & $\begin{array}{c}\text { C setelah } \\
\text { adsorpsi (Ca) }\end{array}$ & Co-Ca & (\%) \\
\hline 0,5 & 1,434 & 100,263 & 51,321 & 48,942 & 48,814 \\
\hline 1,0 & 1,068 & 100,263 & 37,864 & 62,299 & 62,136 \\
\hline 1,5 & 0,887 & 100,263 & 31,358 & 68,905 & 68,724 \\
\hline 2,0 & 0,809 & 100,263 & 28,511 & 71,752 & 71,564 \\
\hline 2,5 & 0,721 & 100,263 & 25,299 & 74,964 & 74,767 \\
\hline
\end{tabular}


Berdasarkan Tabel 1 tersebut dapat diketahui bahwa efisiensi adsorpsi tertinggi terjadi pada massa adsorben sebanyak 2,5 gram. Tabel 2 menunjukkan semakin besar massa bioadsorben yang digunakan, maka efisiensi adsorpsi juga semakin besar.

Untuk mengetahui efisiensi tanaman eceng gondok terhadap zat warna Remazol Golden Yellow dilakukan penelitian dengan memvariasi massa bioadsoben yaitu 0,$5 ; 1,0$; 1,5; 2,0; dan 2,5 gram untuk mengadsorpsi larutan pewarna Remazol Golden Yellow dengan konsentrasi 100 ppm (konsentrasi teoritis) dan waktu adsorpsi 24 jam. Gambar 7 memperlihatkan hubungan antara massa bioadsorben terhadap efisiensi adsorpsi. Dari gambar tersebut menunjukkan bahwa adsorpsi zat warna Remazol Golden Yellow optimum terjadi pada massa eceng gondok 2,5 gram dengan efisiensi adsorpsi sebesar 74,767\%.

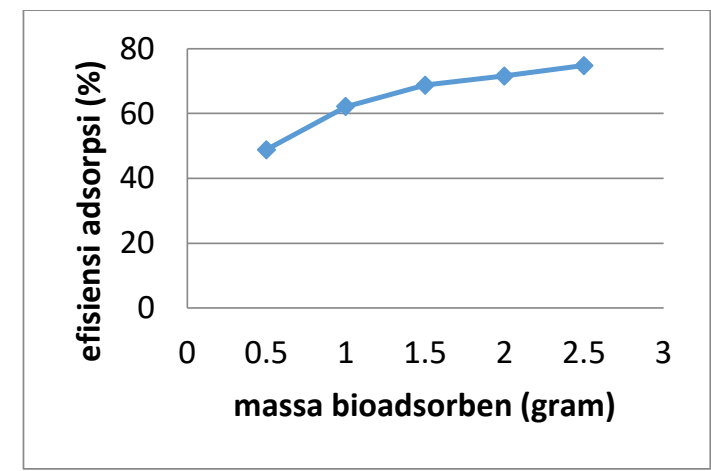

Gambar 3. Kurva hubungan antara Efisiensi adsorpsi (\%) dengan massa adsorben (gram)

Semakin banyak massa bioadsorben yang digunakan maka akan semakin tinggi efisiensi adsorpsinya. Hal itu terjadi karena semakin banyak massa adsorben yang digunakan berarti semakin banyak pula situs aktif dari bioadsorben yang berinteraksi dengan zat warna Remazol Golden Yellow, sehingga kemampuan eceng gondok untuk mendekolorisasi pewarna Remazol Golden Yellow semakin meningkat yaitu dari warna kuning pekat menjadi kuning

\section{Simpulan}

Massa bioadsorben eceng gondok berpengaruh terhadap adsorpsi limbah zat warna Remazol Golden Yellow. Semakin besar massa bioadsorben, efisiensi adsorpsi juga akan semakin besar. Adsorbsi optimum variasi massa terhadap zat warna Remazol Golden Yellow diperoleh pada massa adsorben 2,5 gram/100 mL dengan efisiensi adsorbsi 74,767 $\%$.

\section{Daftar Pustaka}

Al-Kdasi, A., Idris, A., Saed, K. dan Guan. (2004). Treatment of Textile Wastewater by Advanced Oxidation Processes. Global Nest the Int. J. 6: z222-230.

Kun Rifatusholihah. Pengaruh Variasi Massa pada Dekolorisasi Direct Red Teknis dengan Lumpur Aktif dari PT Sari Husada Yogyakarta. Laporan Penelitian Kimia. UNY

Marianto, A.D. (2001). Tanaman Air. Agromedia Pustaka:Jakarta.

Mukti A.M. (2008). Penggunaan Tanaman Eceng gondok Sebagai Pre-treatment Pengelolaan Air Minum. Diakses dariwww.arc.uii.ac.id pada tanggal 23 Agustus 2012.

Nda. (2002). Menyerap Logam Berat dengan Tanaman Air. Diakses dari www.mediaindo.co.id pada tanggal 22 Agustus 2012

Nurul Khotimah, Fitria Hastami, dan Zuhdi Ismail. (2010). Adsorbsi Logam Kromium (IV) Oleh Biomassa Chara fragilis Menggunakan Spektroskopi Serapan Atom. PKM-GT. UNS

R.D. Ratnani, (2008). Pemanfaatan Eceng Gondok (Eichornia Crassipes) Untuk Menurunkan Kandungan COD. Diakses dari

http://eprints.undip.ac.id/1529/1/Ma kalah Penelitian.pdf

Sastroutomo, S. S. 1990. Ekologi Gulma. Jakarta: Penerbit PT Gramedia Pustaka.

ST Ambrosio, GM Campos-Takaki. (2004). Decolorization of reactive azo dyes by 
Cunninghamella elegans UCP 542 under cometabolic conditions. Bioresource Technology.2004 Jan ; 91(1):69-75.

Sukardjo. (1985). Kimia Fisika. Yogyakarta: Bima Aksara.

V. Chandra. (2011). Spektrofotometri. Diakses dari

http://repository.usu.ac.id/bitstream/ 123456789/25178/4/Chapter\%20II.p $\underline{\mathrm{df}}$

Van der Zee. (2002). Anaerobic azo dye reduction. Thesis. Wageningen University. Netherlands.

Wesenberg, D., Kyriakides, I., Agathos, S.N., (2003). White-rot fungi and their enzymes for the treatment of industrial dye effluents. Biotechnol.Adv. 22, 161.187.

Wong, P.K., Yuen, P.Y., (1996). Decolourisation and Biodegradation of Methyl Red by Klebsiella pneumoniaeR-13. Water Res. 30, 1736-1744. 